\title{
A New Chelating Resin Containing Indole-Methionine Composite: Synthesis, Characterization and Determination of Lead and Silver after Preconcentration in Biological and Environmental Samples
}

\author{
Animesh Sahana, ${ }^{a}$ Srikanta Mandal, ${ }^{a}$ Arnab Banerjee, ${ }^{a}$ Subarna Guha, ${ }^{a}$ \\ Subhra Kanti Mukhopadhyay, ${ }^{*, b}$ and Debasis Das*,a \\ ${ }^{a}$ Department of Chemistry and ${ }^{b}$ Department of Microbiology, \\ The University of Burdwan, Burdwan 713104, India
}

\begin{abstract}
O esqueleto indólico modificado com L-metionina foi imobilizado em uma matriz polimérica de poliestireno-divinilbenzeno e mostrou ser seletivo para a determinação dos íons $\mathrm{Pb}$ (II) em pH 8,0 e $\mathrm{Ag}(\mathrm{I}) \mathrm{em} \mathrm{pH}$ 6,5. A capacidade máxima de adsorção da resina modificada é de $0,35 \mathrm{mmol} \mathrm{g}^{-1}$ para $\mathrm{Pb}$ (II) em $\mathrm{pH} 8,0$ e de $1,5 \mathrm{mmol} \mathrm{g}^{-1}$ para $\mathrm{Ag}$ (I) em $\mathrm{pH}$ 6,5. A resina final e seus precursores foram caracterizados por diferentes técnicas instrumentais. O limite de detecção estabelecido (calculado como 3 vezes o desvio padrão do branco) foi de $30 \mathrm{ng} \mathrm{mL}^{-1}$ para o $\mathrm{Pb}(\mathrm{II})$ e de $38 \mathrm{ng} \mathrm{mL}^{-1}$ para $\mathrm{Ag}(\mathrm{I})$. Os percentuais de recuperação foram de $97,4 \pm 2,6 \%$ para o $\mathrm{Pb}$ (II) ao nível da confiança de $98 \%$ e de $98,2 \pm 3,4 \%$ para $\mathrm{Ag}(\mathrm{I})$ ao nível da confiança de $97 \%$. O procedimento desenvolvido foi aplicado com sucesso para a preconcentração de $\mathrm{Pb}(\mathrm{II})$ e $\mathrm{Ag}(\mathrm{I})$ em diferentes amostras ambientais e biológicas. A quantificação de $\mathrm{Pb}(\mathrm{II})$ foi efetuada por espectrometria de absorção atômica com chama (FAAS) enquanto que para $\mathrm{Ag}(\mathrm{I})$ foi empregado um contador de cintilação no qual um cristal de iodeto de sódio dopado com tálio $[\mathrm{NaI}(\mathrm{Tl})]$ foi usado como detector.
\end{abstract}

Derivatized L-methionine having indole backbone has been anchored on polystyrenedivinylbenzene matrix and has been found to have selective binding ability for $\mathrm{Pb}$ (II) and $\mathrm{Ag}(\mathrm{I})$ ions at $\mathrm{pH} 8.0$ and 6.5 , respectively. Maximum capacity for $\mathrm{Pb}(\mathrm{II})$ at $\mathrm{pH} 8.0$ is $0.35 \mathrm{mmol} \mathrm{g}^{-1}$ and for $\mathrm{Ag}(\mathrm{I})$ at $\mathrm{pH} 6.5$ is $1.5 \mathrm{mmol} \mathrm{g}^{-1}$. The final resin and its precursors are fully characterized by different instrumental techniques. Detection limits $(3 \times$ standard deviation of the blank signal $)$ were $30 \mathrm{ng} \mathrm{mL}^{-1}$ for $\mathrm{Pb}(\mathrm{II})$ and $38 \mathrm{ng} \mathrm{mL}^{-1}$ for $\mathrm{Ag}(\mathrm{I})$. Recoveries were found to be $97.4 \pm 2.6 \%$ for $\mathrm{Pb}(\mathrm{II})$ at $98 \%$ confidence level and $98.2 \pm 3.4 \%$ for $\mathrm{Ag}(\mathrm{I})$ at $97 \%$ confidence level. The developed procedure has been successfully applied for preconcentration of $\mathrm{Pb}(\mathrm{II})$ and $\mathrm{Ag}(\mathrm{I})$ in different environmental and biological samples. The concentration of $\mathrm{Pb}(\mathrm{II})$ was determined by flame atomic absorption spectrometry (FAAS) and that of $\mathrm{Ag}(\mathrm{I})$ ion by using a scintillation counter equipped with a well type $\mathrm{NaI}(\mathrm{Tl})$ crystal detector.

Keywords: derivatized L-methionine, indole, chelating resin, polystyrene, lead, silver, FAAS, scintillation detector, application

\section{Introduction}

Heavy metal pollution of the environment, particularly by lead has received a considerable attention as it leads to many fatal diseases including dysfunction of renal blood and neurological systems. ${ }^{1}$ Again, $\mathrm{Pb}(\mathrm{II})$ easily deposits in brain, kidney, reproductive and nervous systems. Acute lead poisoning can result severe anemia, colic shock and irreversible brain damage. Several works on the solid phase extraction of lead by incorporating different chelating

*e-mail: ddas100in@yahoo.com groups on the polymer backbone has been reported. Among them, 2-aminothiophenyl-S-acetic acid, ${ }^{2}$ dithiooxamide, ${ }^{3}$ oxine, ${ }^{4}$ resacetophenone, ${ }^{5} \mathrm{o}$-aminophenol, ${ }^{6} \mathrm{o}$-aminobenzoic acid, ${ }^{7}$ zirconium phosphate, ${ }^{8}$ pyrocatechol violet ${ }^{9}$, quinalizarin ${ }^{10}$ and imidazolylazo ${ }^{11}$ anchored/supported polymers are noteworthy. Recovery of silver ion from photographic industrial wastes, selective removal of silver ion from medicinal samples and its ores have immense importance. Selective removal and preconcentration of silver from different samples were investigated by different workers. ${ }^{12,13}$ Several analytical methods like 
spectrophotometry, polarography, flame atomic absorption spectrometry (FAAS), graphite furnace atomic absorption spectrometry (GFAAS), inductively coupled plasma optical emission spectrometry (ICP OES), inductively coupled plasma mass spectrometry (ICP-MS) are available for quantitative estimation of lead with different sensitivities. Different techniques used for the selective separation of lead include liquid-liquid extraction, solid-phase extraction, liquid membrane and cloud point extraction, etc.

Our research goal is to synthesize different potential organic ligands which have specific metal ion binding affinity. The ligand then anchored to polymeric matrix to make a suitable platform through which the solution containing metal ions can pass through. Recently derivatized amino acids having a tripodal ligand motif have attracted immense interest as it is used in the development of chirality switch, ${ }^{14-16}$ to modeling the structure and function of zinc enzymes like carboxypeptidase, ${ }^{17}$ superoxide dismutase, ${ }^{18}$ alkaline phosphatase, ${ }^{19}$ L-fuculose-1-phosphate aldolase. ${ }^{20}$ Because of its rich chemistry and the wide area that remains uncovered, we are presently working on the synthesis of different derivatized chiral amino acids, their structural characterization, metal ion uptake properties and applications of these new series of ligands.

Herein we report synthesis of indole containing derivatized L-methionine which has been incorporated to the polymeric framework to have an efficient trace level separation of lead and silver. It is found that incorporation of indole moiety into L-methionine part increases the absorption capacity of the soft metal ions like $\mathrm{Pb}$ (II) and Ag(I) over simply using L-methionine because indole contains a soft nitrogen donor site. Concentrations of lead and silver have been determined by FAAS and a scintillation counter equipped with a well type $\mathrm{NaI}(\mathrm{Tl})$ crystal detector, respectively. Because of high sensitivity, rapidity, operational simplicity, low operational cost of measurements over the other standard methods, estimation of silver was monitored radiometrically using ${ }^{110 \mathrm{~m}} \mathrm{Ag}$.

\section{Experimental}

\section{Apparatus}

A VARIAN (Spectra AA 55, Mulgrave, Australia) flame atomic absorption spectrometer was used. All measurements were performed using integrated absorbance (peak area). Hollow cathode lamp for $\mathrm{Pb}$ was operated at $10.0 \mathrm{~mA}$ and the wavelength $217 \mathrm{~nm}$ was selected using a spectral resolution of $1 \mathrm{~nm}$. Air and acetylene gases have flow rates 3.5 and $1.5 \mathrm{~L} \mathrm{~min}^{-1}$, respectively. The radioactivity was measured by a scintillation counter equipped with a well type $\mathrm{NaI}$ (Tl) crystal detector (Nucleonix, India). IR spectra were recorded on a JASCO FTIR spectrophotometer (model FT-IR-H20, U.K.). Measurements of $\mathrm{pH}$ were performed with Systronics digital pHmeter (model 335, Systronics, India). UV-Vis spectra were obtained from a Shimadzu spectrophotometer (model UV2101PC, Japan). A Kratos MALDI-TOF 1 mass spectrometer using the matrix $\alpha$-ACHC and an extraction voltage of $4 \mathrm{kV}$ was used for mass spectrometry (Japan). ${ }^{1} \mathrm{H}$ NMR and ${ }^{13} \mathrm{C}$ NMR spectra were recorded on a 200 and $50 \mathrm{MHz}$ Varian Gemini 200 and optical rotations were determined on a Perkin-Elmer model 341 polarimeter at $589 \mathrm{~nm}$ (U.S.A.). Thermogravimetric analysis was done on a Perkin Elmer TG/DTA Lab System 1 (Technology by SII). A domestic Samsung microwave oven (model CE2933) with a $2450 \mathrm{MHz}$ frequency magnetron and $900 \mathrm{~W}$ maximum applied power and a polytetrafluoroethylene (PTFE) reactor (115 mL internal volume, $1 \mathrm{~cm}$ cell wall thickness and hermetic screw caps) were used for sample digestion.

\section{Reagents and solutions}

Stock solution of $\mathrm{Pb}(\mathrm{II})$ (1000 $\mathrm{mg} \mathrm{L}^{-1}$ in $3 \% \mathrm{v} / \mathrm{v} \mathrm{HNO}_{3}$ ) was obtained from SOLUTIONS Plus Inc. (Missouri, USA) which was tested versus NIST SRM \# 3108a (Gaithersburg, MD, USA). Then the solution was diluted 20 times for our practical work. All the working solutions were prepared by appropriate dilution with deionised water. ${ }^{110 \mathrm{~m}} \mathrm{Ag}$ was supplied by Bhaba Atomic Research Centre, Trombay, and used as tracers. All other chemicals were reagent grade. Glass apparatus were soaked in $4.0 \mathrm{~mol} \mathrm{~L}-1 \mathrm{HNO}_{3}$ overnight and cleaned with double distilled water. Certified reference materials analyzed were: standard reference material (SRM) 1573 tomato leaves from National Bureau of Standards; pond sediment (NIES 2, Tsukuba-city, Japan); and igneous rock (JR-1) from National Institute for Environmental Studies. Different buffer solutions were used for adjusting the $\mathrm{pH}$ and prepared according to literature procedure, i.e. citrate buffer ( $\mathrm{pH} 3.0-6.0)$, phosphate buffer ( $\mathrm{pH}$ 7.0-8.0), boric acid-borax buffer ( $\mathrm{pH} 9.0)$, glycine$\mathrm{NaOH}$ buffer (pH 10.0) solutions.

\section{Preparation of the resin}

\section{Synthesis of N-(3-indolylmethyl) L-methionine (IM)}

Method 1:21 To a solution of $1.9 \mathrm{~g}$ of L-methionine (13.0 mmol) dissolved in $50 \mathrm{~mL}$ of $4.0 \mathrm{~mol} \mathrm{~L}^{-1} \mathrm{NaOH}, 2.0 \mathrm{~g}$ of 3-indolecarboxyaldehyde (13.78 mmol, 1 equiv.) was added under stirring over a period of about $1 \mathrm{~h}$. The stirring was continued for additional $2 \mathrm{~h}$ followed by addition of $0.5 \mathrm{~g} \mathrm{NaBH}_{4}$ in small portions. Stirring was continued till foaming ceases. Then the $\mathrm{pH}$ of the solution was adjusted to 
3.0 with $6.0 \mathrm{~mol} \mathrm{~L}^{-1} \mathrm{HCl}$. Some suspended particulates were separated by filtration. The volume of the filtrate reduced to $20 \mathrm{~mL}$ by vacuum distillation and kept overnight. The orange crystalline product was isolated and dried. Yield was $55 \%$; mp $112^{\circ} \mathrm{C}$.

Method 2:22 To a $100 \mathrm{~mL}$ dichloromethane solution containing L-methionine methyl ester hydrochloride $(1.0 \mathrm{~g}$, $5.0 \mathrm{mmol}), 1$ equiv. of 3 -indolecarboxyaldehyde $(0.73 \mathrm{~g}$, $5 \mathrm{mmol}$ ) was added. To this mixture, $20 \mathrm{~mL}$ triethylamine and $6.0 \mathrm{~g}$ anhydrous magnesium sulphate were added under stirring condition for $1 \mathrm{~h}$ at room temperature. Filtration, removal of solvent, water-ether partitioning and finally removal of ether yielded $70 \%$ of the Schiff base ester. A mass of $1.0 \mathrm{~g}$ of this ester was dissolved in THF and subjected to hydrolysis with $0.5 \mathrm{~mol} \mathrm{~L}^{-1}(20 \mathrm{~mL})$ aqueous $\mathrm{LiOH}$ at room temperature for $4 \mathrm{~h}$. The solvent was removed under reduced pressure and subjected to waterdichloromethane partitioning to remove any unreacted ester or other impurities. To the aqueous part, $0.4 \mathrm{~g} \mathrm{NaBH}_{4}$ in small portions was added under stirring condition till foaming ceases. The $\mathrm{pH}$ of the aqueous part was maintained at 7.0-7.5 with diluted $\mathrm{HCl}$ solution and extracted with ethyl acetate. Traces of water were removed by anhydrous $\mathrm{Na}_{2} \mathrm{CO}_{3}$. Solvent was removed under reduced pressure and the desired compound was crystallized from methanol. Yield was $65 \%$; ${ }^{1} \mathrm{H} \mathrm{NMR}\left(200 \mathrm{MHz}, \mathrm{CDCl}_{3}\right.$, peaks of the spectrum are relatively broad) $\delta 1.85\left(2 \mathrm{H}, \mathrm{m}, \mathrm{CH}_{2}\right), 2.12$ $\left(3 \mathrm{H}, \mathrm{s}, \mathrm{CH}_{3}\right), 2.42\left(2 \mathrm{H}, \mathrm{m}, \mathrm{CH}_{2}\right), 3.25(1 \mathrm{H}, \mathrm{s}, J 7 \mathrm{~Hz}, \mathrm{CH})$, $3.62\left(2 \mathrm{H}, \mathrm{m}, \mathrm{CH}_{2}\right), 7.63(1 \mathrm{H}, \mathrm{d}), 7.15(1 \mathrm{H}, \mathrm{t}), 7.01(1 \mathrm{H}, \mathrm{t})$, $7.35(1 \mathrm{H}, \mathrm{d}) ;{ }^{13} \mathrm{CNMR}\left(50 \mathrm{MHz}, \mathrm{CDCl}_{3}\right) \delta 15.95,26.82$, 34.05, 56.16, 64.18, 122.56, 130.15, 125.5, 132.3, 133; MS $(m / z) 279.63(\mathrm{M}+\mathrm{H})^{+}$. Calculated for $\mathrm{C}_{14} \mathrm{H}_{18} \mathrm{~N}_{2} \mathrm{O}_{2} \mathrm{~S}$ : C, 60.41; H, 6.52; N, 10.06. Found: C, 60.21; H, 6.62; N, $10.16 \%$. FT-IR $v_{\max } / \mathrm{cm}^{-1} 1622(\mathrm{CO}), 3393(\mathrm{OH}) . \mathrm{UV}-\mathrm{Vis}$ $\lambda_{\max } / \mathrm{nm}$ (acetonitrile) $392\left(\varepsilon / \mathrm{dm}^{3} \mathrm{~mol}^{-1} \mathrm{~cm}^{-1} 87 \times 10^{3}\right), 372$ $\left(\varepsilon / \mathrm{dm}^{3} \mathrm{~mol}^{-1} \mathrm{~cm}^{-1} 83 \times 10^{3}\right) ; 354\left(\varepsilon / \mathrm{dm}^{3} \mathrm{~mol}^{-1} \mathrm{~cm}^{-1} 78 \times 10^{3}\right)$, $334\left(\varepsilon / \mathrm{dm}^{3} \mathrm{~mol}^{-1} \mathrm{~cm}^{-1} 37 \times 10^{3}\right) ;[\alpha]^{25}{ }_{\mathrm{D}}=+71^{\circ}$.

$N$-(3-Indolylmethyl) L-methionine (IM) $2.0 \mathrm{~g}$ is mixed with commercially available chloromethylated polystyrenedivinylbenzene (2\%) (2 g) and $\mathrm{NaHCO}_{3}(4 \mathrm{~g})$ and refluxed for $8 \mathrm{~h}$ in dehydrated alcohol. The color of the insoluble desired resin becomes brown. The resin is filtered through sintered glass Gooch crucible ( $\mathrm{G} 4$ ), washed with double distilled water to free from alkali and dried under vacuum. The bead size of the resin is 120-140 mesh.

\section{Stability of the resin}

A mass of $250 \mathrm{mg}$ of resin was shaken with $100 \mathrm{~mL}$ of acid and alkaline solutions (separately) of different concentrations for 7 days. Then filtered and washed with double distilled water to free from acid or alkali and dried under vacuum. The metal ion exchange capacity was measured. To study the effect of radiation on the resin matrix, the resin was exposed to $\gamma$-radiation for $48 \mathrm{~h}$. As, measurement of water regain of the resin requires elevated temperature, so we have to be sure that resin remains unaltered at this elevated temperature $\left(100{ }^{\circ} \mathrm{C}\right)$. The experiment was made thermogravimetrically (TGA / DTG).

\section{Water regain}

Air dried resin in basic form was stirred in double distilled water for $48 \mathrm{~h}$, then filtered off by suction, weighed, dried at $100{ }^{\circ} \mathrm{C}$ for $48 \mathrm{~h}$ and reweighed.

\section{Hydrogen ion capacity}

A mass of $0.5 \mathrm{~g}$ resin was first converted into its acidic form by treating with $6.0 \mathrm{~mol} \mathrm{~L}^{-1} \mathrm{HCl}$. The resin was first filtered off, washed with water and then dried at $100{ }^{\circ} \mathrm{C}$ for $6 \mathrm{~h}$ to remove any free $\mathrm{HCl}$. The acidic hydrogen content of the resin was then determined by back titration with a standard alkali solution. The acidic form of the resin was equilibrated with $20 \mathrm{~mL} 0.1 \mathrm{~mol} \mathrm{~L}^{-1} \mathrm{NaOH}$ solution for $6 \mathrm{~h}$ at room temperature under stirring condition. Then, the solution was filtered under suction, washed with deionised water and the excess alkali was titrated with $0.1 \mathrm{~mol} \mathrm{~L}^{-1}$ standard $\mathrm{HCl}$ solution.

\section{Metal ion capacity as a function of $\mathrm{pH}$}

A batch technique was used by adding metal ion in excess to the resin. Capacities were determined in the $\mathrm{pH}$ range 3.0-10.0. To a glass stopper centrifuge tube (diameter $2.0 \mathrm{~cm}$ ) containing $100 \mathrm{mg}$ of the dry resin in basic form, $10 \mathrm{~mL}$ of the desired $\mathrm{pH}$ solution was added. After equilibration of this mixture, $1 \mathrm{~mL}$ of $0.2 \mathrm{mmol} \mathrm{L}^{-1}$ metal ion solution was added and the mixture was shaken for $24 \mathrm{~h}$. The $\mathrm{pH}$ of the equilibrating solution was adjusted by appropriate buffer solution. After $24 \mathrm{~h}$, the solutions were filtered under suction, washed with double distilled water and the amount of lead in the filtrate was determined by FAAS using air-acetylene flame whereas the amount of sorbed silver ion on the resin was determined by the measurement of the $\gamma$-activity of equal portions of the solutions, before and after the sorption.

\section{Desorption of metal ions}

Resin thus obtained after uptaking of $\mathrm{Pb}(\mathrm{II})$ and $\mathrm{Ag}(\mathrm{I})$ in the above mentioned batch technique was shaken with 
$30 \mathrm{~mL}$ of different eluents $\left(0.01\right.$ to $2 \mathrm{~mol} \mathrm{~L}^{-1} \mathrm{HNO}_{3}$ and also with $5 \% \mathrm{~m} / \mathrm{v}$ thiourea in $0.1 \mathrm{~mol} \mathrm{~L}^{-1} \mathrm{HNO}_{3}$ ) for $6 \mathrm{~h}$ and filtered. The concentration of the metal ion in the filtrate was determined.

\section{Equilibration rates}

Equilibration rates for $\mathrm{Pb}(\mathrm{II})$ and $\mathrm{Ag}(\mathrm{I})$ were studied at $\mathrm{pH} 8.0$ and 6.5 respectively. The time required for $50 \%$ uptake of the metal ion was determined.

\section{Kinetic studies}

The concentrations of $\mathrm{Pb}(\mathrm{II})$ and $\mathrm{Ag}(\mathrm{I})$ absorbed/ adsorbed by the resin at the $\mathrm{pH}$ where maximum sorption takes place were monitored at different time intervals. From those data, rate constants were determined for the sorptions of $\mathrm{Pb}(\mathrm{II})$ and $\mathrm{Ag}(\mathrm{I})$ on the resin using batch mode.

\section{Column operations}

Air dried resin ( $1 \mathrm{~g})$ was immersed in double distilled water and allowed to swell for $24 \mathrm{~h}$. A glass column $(130 \mathrm{~mm} \times 10 \mathrm{~mm})$ was packed with swollen beads to a bed volume of $2 \mathrm{~mL}$. Sorption and desorption characteristics for $\mathrm{Pb}(\mathrm{II})$ and $\mathrm{Ag}(\mathrm{I})$ in the column were studied at a flow rate of $0.5 \mathrm{~mL} \mathrm{~min}^{-1}$. Lead(II) and silver(I) sorption capacity for the non-functionalized chloromethylated resin was measured at $\mathrm{pH} 8.0$ and 6.5 to ascertain that it has no sorption for $\mathrm{Pb}(\mathrm{II})$ and $\mathrm{Ag}(\mathrm{I})$.

\section{Analytical procedure}

Portions (100-150 mg) of the certified reference materials were treated in a hermetically sealed PTFE $(115 \mathrm{~mL})$ reactor in sequence $(450 \mathrm{~W}, 3.0 \mathrm{~min}$ each) with $2 \mathrm{~mL}$ of hydrofluoric acid (HF), $4 \mathrm{~mL}$ of aqua regia and $3 \mathrm{~mL}$ of $\mathrm{H}_{2} \mathrm{O}_{2}$. The digested sample was boiled with saturated boric acid $(8 \mathrm{~mL})$ for $12 \mathrm{~min}$ in a water bath to remove excess HF. Road dust samples from different places on G. T. Road, Burdwan (West Bengal, India) were also digested adopting the same procedure. Surely, safety aspects must be fully considered when working with a microwave oven not designed for laboratorial use and the use of a properly fabricated oven is strongly recommended. Two geological samples, obtained from Geological Survey of India, Kolkata, were also digested. Photographic washings from industrial exhaust and Silverex ointment containing silver were brought into solution by the usual method. ${ }^{23}$

\section{Results and Discussion}

\section{Synthesis and characterization of the resin}

The resin was synthesized by coupling newly synthesized $N$-(3-indolyl) L-methionine (IM, II) with chloromethylated polystyrene-divinylbenzene $(2 \%)$ as shown in Scheme 1. Elemental analysis, NMR, mass spectral data, FT-IR and UV-Vis spectra confirm the structure of $N$-(3-indolylmethyl) L-methionine (IM)
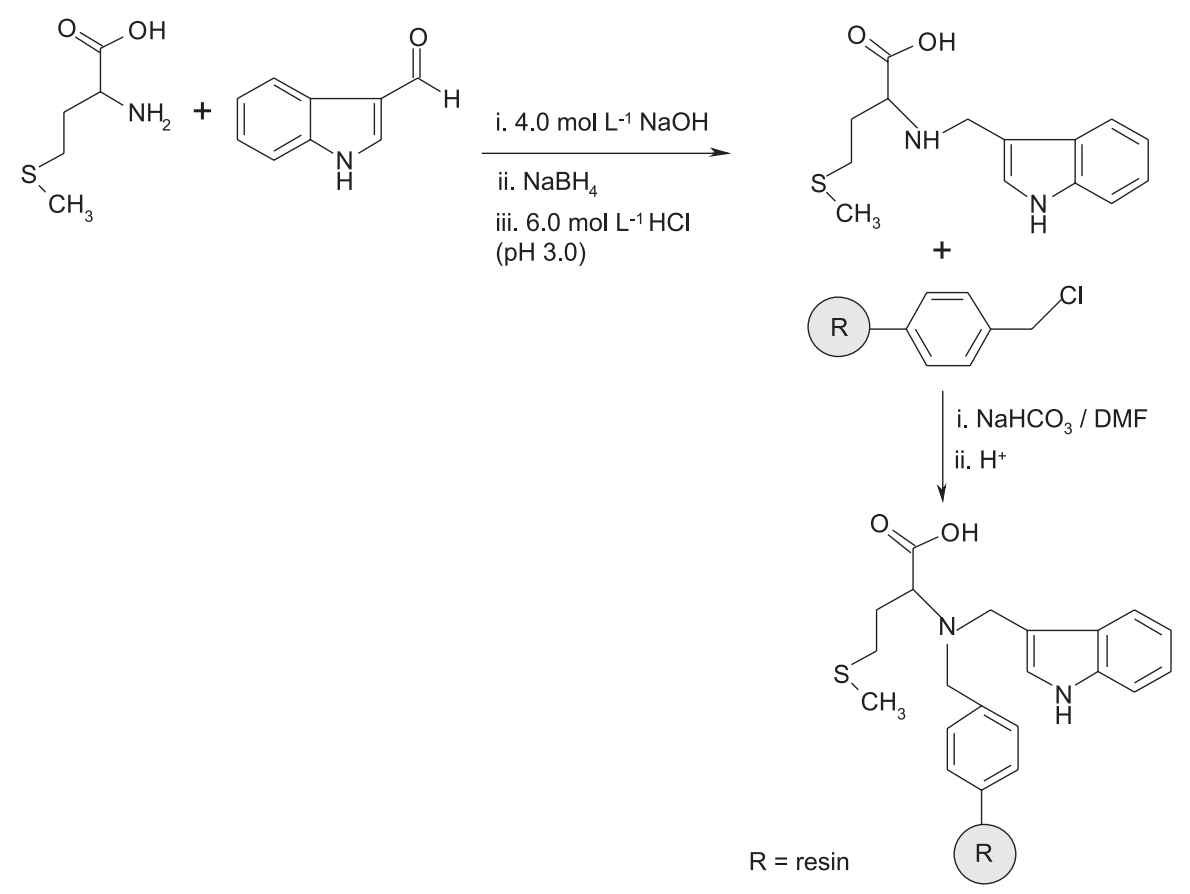

Scheme 1. Synthesis of the chelating resin containing $N$-methyl-3-indolyl L-methionine 
whereas the FT-IR spectra of the final resin (S-1) shows all the characteristics stretching frequencies $\left(v_{\mathrm{CO}} 1602 \mathrm{~cm}^{-1}\right.$; $v_{\mathrm{OH}} 3426 \mathrm{~cm}^{-1}$ and fingerprint regions of methionine and indole i.e. $650-1200 \mathrm{~cm}^{-1}$ ) present in compound (II), thereby indicating the incorporation of the IM moiety to the polymeric matrix.

The chemical stability of the resin in 0.01 to $6.0 \mathrm{~mol} \mathrm{~L}^{-1}$ $\mathrm{HNO}_{3}$ and 0.1 to $6.0 \mathrm{~mol} \mathrm{~L}-1 \mathrm{NaOH}$ was examined. No significant changes in the structure of the resin was observed as evident from comparison of FT-IR spectra as well as metal ion and hydrogen ion exchange capacities of the treated resin with the untreated one. Thus the resin is fairly stable in both acidic and alkaline conditions. Thermogravimetric analysis showed that the resin is fairly stable up to $130^{\circ} \mathrm{C}(\mathrm{S}-2)$. The time required for $50 \%$ uptake of the maximum capacity was found to be 28 and $32 \mathrm{~min}$ for $\mathrm{Pb}(\mathrm{II})$ and $\mathrm{Ag}(\mathrm{I})$ ions, respectively.

It is observed that the flow rate of the sample solution had an immense effect on the retention of metal ions on the resin. It was found that up to a flow rate of $5.0 \mathrm{~mL} \mathrm{~min}^{-1}$, the sorption of $\mathrm{Pb}(\mathrm{II})$ is maximum, after that it decreases. The observed behavior for $\operatorname{Ag}(\mathrm{I})$ was similar. The water regain value for the resin is 12 , which is satisfactory for column operation.

\section{Sorption and desorption of metal ion}

The hydrogen ion capacity of the resin was found to be $2.35 \mathrm{mmol} \mathrm{g}^{-1}$. Maximum capacity for $\mathrm{Pb}$ (II) at $\mathrm{pH} 8.0$ is $0.35 \mathrm{mmol} \mathrm{g}^{-1}$ and for $\mathrm{Ag}(\mathrm{I})$ at $\mathrm{pH} 6.5$ is $1.5 \mathrm{mmol} \mathrm{g}^{-1}$. The sorption capacity of the resin for $\mathrm{Pb}(\mathrm{II})$ and $\mathrm{Ag}(\mathrm{I})$ as a function of $\mathrm{pH}$ is shown in Figure 1. All the characteristics band of the IM resin undergo a red shift upon binding with $\mathrm{Pb}$ (II) and $\mathrm{Ag}(\mathrm{I})$ ions as evident from S-3 and S-4 respectively.

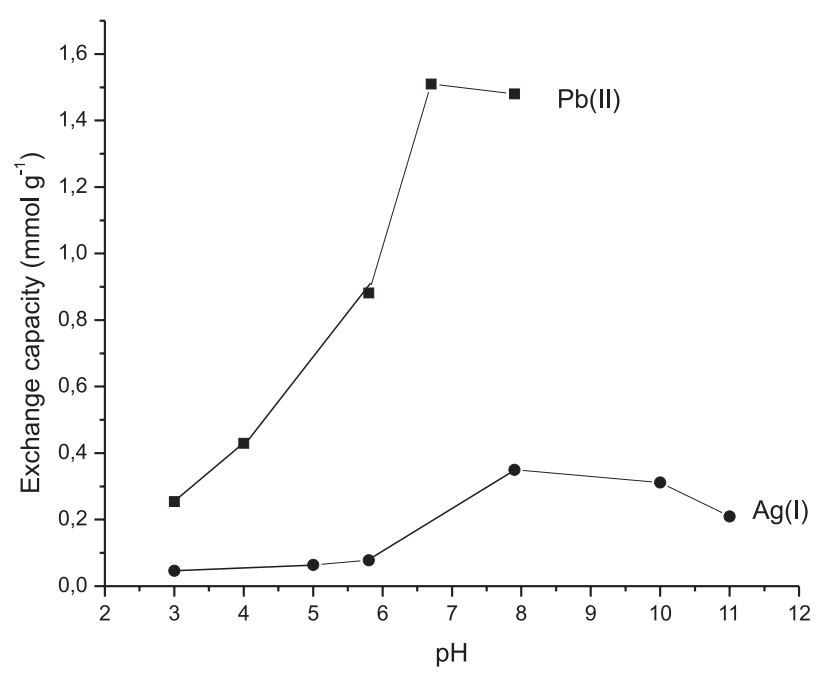

Figure 1. Sorption of $\mathrm{Pb}(\mathrm{II})$ and $\mathrm{Ag}(\mathrm{I})$ on the resin as a function of $\mathrm{pH}$.

\section{Kinetic parameters}

The rate of exchange of metal ion by a chelating resin is controlled by a second order kinetic equation, ${ }^{24} \ln \mathrm{Z}=2 \mathrm{kQ}_{0}$ $\left(\mathrm{Q}_{0}-\mathrm{Q}_{\alpha}\right) \mathrm{t} / \mathrm{Q}_{\alpha}$, where $\mathrm{Z}=\left[\mathrm{Q}_{\mathrm{t}}\left(\mathrm{Q}_{0}-2 \mathrm{Q}_{\alpha}\right)+\mathrm{Q}_{0} \mathrm{Q}_{\alpha}\right] / \mathrm{Q}_{0}$ $\left(Q_{\alpha}-Q_{t}\right)$ as developed by Turse and Rieman. ${ }^{25}$ The rate constant $\mathrm{k}$ is calculated from the slope $\mathrm{S}$ of the equation: $\mathrm{S}=2 \mathrm{kQ}_{0}\left(\mathrm{Q}_{0}-\mathrm{Q}_{\alpha}\right) / \mathrm{Q}_{\alpha}$, where $\mathrm{Q}_{\mathrm{t}}$ is the amount of metal ion (in mmol) exchanged at time $t, \mathrm{Q}_{\alpha}$ is the maximum exchange capacity at equilibrium and $\mathrm{Q}_{0}$ is the amount of chelating resin, in terms of milimoles of $\mathrm{Na}^{+}$exchanged after $24 \mathrm{~h}$. Thus, a plot of $\ln \mathrm{Z}$ versus $\mathrm{t}$ should be linear passing through zero for a second order exchange. We got the linear equations for $\mathrm{Pb}$ (II) as $\ln \mathrm{Z}=0.03607 \mathrm{t}+0.364 \times 10^{-4}$ and for $\mathrm{Ag}(\mathrm{I})$ as $\ln Z=0.03592 t+0.4704 \times 10^{-4}$ respectively. The values for rate constant ( $\mathrm{k}$ ) for the chelation of $\mathrm{Pb}$ (II) and $\mathrm{Ag}$ (I) by this new resin as obtained from the linearly fit second order plots are $1.134 \times 10^{-3}$ and $1.31 \times 10^{-2}$ respectively.

\section{Effect of foreign ions}

In column operation, the presence of macro amounts of diverse metal ions like alkaline and alkaline earth metal ions had no interferences. Amongst transition metal ions, $\mathrm{Cu}(\mathrm{II})$, $\mathrm{Hg}$ (II), and Cd(II) interfered, while others did not (Table 1).

Table 1. Tolerance limits of diverse ions

\begin{tabular}{lcc}
\hline Diverse ions & \multicolumn{2}{c}{ Foreign ion to analyte ratio* } \\
& $\mathrm{Pb}(\mathrm{II})$ & $\mathrm{Ag}(\mathrm{I})$ \\
\hline $\mathrm{K}^{+}, \mathrm{Na}^{+}, \mathrm{Ca}^{2+}, \mathrm{Mg}^{2+}$ & 5000 & 5000 \\
$\mathrm{Al}^{3+}, \mathrm{Be}^{2+}, \mathrm{Fe}^{3+}, \mathrm{Cr}^{3+}$ & 1000 & 2000 \\
$\mathrm{Cu}^{2+}, \mathrm{Co}^{2+}, \mathrm{Zn}^{2+}, \mathrm{Ni}^{2+}, \mathrm{Mn}^{2+}$ & 500 & 900 \\
$\mathrm{Hg}^{2+}, \mathrm{Cd}^{2+}$ & 50 & 100 \\
$\mathrm{NO}_{3}^{-}, \mathrm{SO}_{4}^{2-}, \mathrm{Cl}^{-}, \mathrm{Br}^{-}, \mathrm{I}^{-}$, & 5000 & 5000 \\
\hline
\end{tabular}

* No interference observed.

\section{Effect of eluent type and volume}

In order to elute sorbed $\mathrm{Pb}(\mathrm{II})$ and $\mathrm{Ag}(\mathrm{I})$ from the resin, different eluting agents were tested as described in Table 2. It was observed that $5.0 \mathrm{~mL}$ of $5 \% \mathrm{~m} / \mathrm{v}$ thiourea in $0.1 \mathrm{~mol} \mathrm{~L}^{-1} \mathrm{HNO}_{3}$ and $10.0 \mathrm{~mL}$ of $5 \% \mathrm{~m} / \mathrm{v}$ thiourea in $0.1 \mathrm{~mol} \mathrm{~L}^{-1} \mathrm{HNO}_{3}$ can completely desorb $\mathrm{Pb}$ (II) and $\mathrm{Ag}$ (I) from the resin bed, respectively.

\section{Effect of sample volume}

In order to deal with real samples, the maximum applicable sample volume must be determined for the 
Table 2. Percentual recoveries of $\mathrm{Pb}(\mathrm{II})$ and $\mathrm{Ag}(\mathrm{I})$ using different eluents $(\mathrm{n}=4$, mean \pm standard deviation $)$

\begin{tabular}{|c|c|c|}
\hline Eluent & Recovery $\%$ of $\mathrm{Pb}(\mathrm{II})$ & Recovery $\%$ of $\operatorname{Ag}(\mathrm{I})$ \\
\hline $0.01 \mathrm{~mol} \mathrm{~L}^{-1} \mathrm{HNO}_{3}$ & $60 \pm 0.3$ & $65 \pm 0.5$ \\
\hline $0.1 \mathrm{~mol} \mathrm{~L}^{-1} \mathrm{HNO}_{3}$ & $68 \pm 0.6$ & $72 \pm 0.8$ \\
\hline $1.0 \mathrm{~mol} \mathrm{~L}^{-1} \mathrm{HNO}_{3}$ & $72 \pm 0.7$ & $80 \pm 0.9$ \\
\hline $2.0 \mathrm{~mol} \mathrm{~L}^{-1} \mathrm{HNO}_{3}$ & $82 \pm 0.8$ & $92 \pm 0.8$ \\
\hline $\begin{array}{l}0.1 \mathrm{~mol} \mathrm{~L}^{-1} \mathrm{HNO}_{3}+ \\
5 \% \mathrm{~m} / \mathrm{v} \text { thiourea }\end{array}$ & $99.2 \pm 0.2$ & $101 \pm 0.5$ \\
\hline
\end{tabular}

solid phase extraction studies. A volume of $300 \mathrm{~mL}$ of stock solution (concentration $50 \mathrm{mg} \mathrm{L}^{-1}$ ) of $\mathrm{Pb}$ (II) was passed through the column under the optimum condition of flow rate, i.e. $5 \mathrm{~mL} \mathrm{~min}{ }^{-1}$. The recovery of $\mathrm{Pb}$ (II) was quantitative (96\%) up to $160.0 \mathrm{~mL}$ of sample volume for $1 \mathrm{~g}$ resin. Above $160.0 \mathrm{~mL}$ the recovery decreased quickly with increasing sample volume. Likewise $1000 \mathrm{~mL}$ stock solution (concentration $50 \mathrm{mg} \mathrm{L}^{-1}$ ) of $\mathrm{Ag}(\mathrm{I})$ was passed through the column under the optimum condition of flow rate, again $5 \mathrm{~mL} \mathrm{~min}^{-1}$. The recovery of $\mathrm{Ag}(\mathrm{I})$ was quantitative (97\%) up to $435.0 \mathrm{~mL}$ of sample volume for $1 \mathrm{~g}$ resin.

\section{Evaluation of method performance}

Calibration curve for quantitative analysis was linear up to $8 \mu \mathrm{g} \mathrm{mL}^{-1}$ with a regression coefficient $r^{2}=0.997$.
Detection limits ( $3 \sigma$ of the blank signal) were 30 and $38 \mathrm{ng} \mathrm{mL}^{-1}$ for $\mathrm{Pb}(\mathrm{II})$ and $\mathrm{Ag}(\mathrm{I})$, respectively. Precision of the method was evaluated by successive retention and elution cycle with $0.1 \mathrm{~g}$ of the metal ions in $100 \mathrm{~mL}$ of solution. Recovery was $97.4 \pm 2.6 \%$ for $\mathrm{Pb}$ (II) at $98 \%$ confidence level and $98.2 \pm 3.4 \%$ for $\mathrm{Ag}(\mathrm{I})$ at $97 \%$ confidence level.

\section{Real samples analysis}

To establish the accuracy of the developed method, certified and real samples were digested using a microwaveassisted procedure and the separation of $\mathrm{Pb}(\mathrm{II})$ and $\mathrm{Ag}(\mathrm{I})$ were carried out using the newly synthesized resin, followed by its determination using FAAS and scintillation counter, respectively. Results are presented in Tables 3 and 4 and

Table 3. Analysis of certified reference materials and real samples for $\mathrm{Pb}$ (II) $\left(\mu \mathrm{g} \mathrm{g}^{-1}, \mathrm{n}=4\right.$, mean \pm standard deviation $)$

\begin{tabular}{lccc}
\hline Sample & $\begin{array}{c}\text { Certified or } \\
\text { Reference Value }\end{array}$ & $\begin{array}{c}\text { Determined } \\
\text { Value }\end{array}$ & Error \% \\
\hline Tomato leaves & $6.3 \pm 0.3$ & $6.5 \pm 0.8$ & 3.17 \\
Pond sediment & $105 \pm 6$ & $102 \pm 2$ & 2.65 \\
Igneous rock & $19.1 \pm 0.3$ & $20.0 \pm 1.6$ & 4.71 \\
Road dust I & $118 \pm 6^{*}$ & $124 \pm 0.9$ & 5.08 \\
Road dust II & $59 \pm 3^{*}$ & $62 \pm 1.3$ & 5.08 \\
\hline
\end{tabular}

* Direct analysis.

Table 4. Determination of $\mathrm{Ag}(\mathrm{I})$ ion real samples $\left(\mu \mathrm{g} \mathrm{g}^{-1}, \mathrm{n}=4\right.$, mean \pm standard deviation)

\begin{tabular}{lccc}
\hline Sample & Reference value & Determined value & \% Error \\
\hline Silverex & $1.5^{\mathrm{a}} \pm 0.3$ & $1.6 \pm 0.6$ & 0.1 \\
Photographic washings & $59.31^{\mathrm{a}} \pm 0.5$ & $57.81 \pm 0.8$ & 1.5 \\
Geological samples from G. S. I., Kolkata & $600^{\mathrm{a}, \mathrm{b}} \pm 0.2$ & $590 \pm 0.8$ & 10 \\
\hline
\end{tabular}

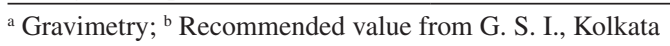

Table 5. Comparison of the developed procedure with some other proposed procedures

\begin{tabular}{|c|c|c|c|}
\hline Resin & $\begin{array}{l}\mathrm{LOD} \text { for } \mathrm{Pb}(\mathrm{II}) / \\
\mathrm{Ag}(\mathrm{I})\left(\mathrm{ng} \mathrm{mL}^{-1}\right)\end{array}$ & $\begin{array}{l}\text { Sorption capacity } \\
\left(\mathrm{mmol} \mathrm{g}^{-1}\right)\end{array}$ & Samples \\
\hline $\begin{array}{l}\text { 6-Mercaptopurine appended polystyrene- } \\
\text { divinylbenzene through azo linker [ref. 26] }\end{array}$ & $\operatorname{Ag}(I): 29$ & $\operatorname{Ag}(\mathrm{I}): 0.52$ & $\begin{array}{l}\text { Geological, medicinal and } \\
\text { environmental samples }\end{array}$ \\
\hline $\begin{array}{l}\text { Benzimidazolylazo appended polystyrene- } \\
\text { divinylbenzene copolymer [ref. 13] }\end{array}$ & NA & $\operatorname{Ag}(\mathrm{I}): 1.0$ & $\begin{array}{l}\text { Rock samples, chawanprash (DABUR), } \\
\text { sulfadiazine (Silverex), photographic washings }\end{array}$ \\
\hline $\begin{array}{l}\text { Imidazolylazo appended polystyrene- } \\
\text { divinylbenzene copolymer [ref. 27] }\end{array}$ & NA & $\operatorname{Ag}(\mathrm{I}): 1.49$ & $\begin{array}{l}\text { Rock samples, chawanprash (DABUR), } \\
\text { sulfadiazine (Silverex), photographic washings }\end{array}$ \\
\hline $\begin{array}{l}\text { 2-Aminothiazole appended polystyrene- } \\
\text { divinylbenzene through azo linker [ref. 28] }\end{array}$ & $\mathrm{Pb}(\mathrm{II}): 25$ & $\mathrm{~Pb}(\mathrm{II}): 0.29$ & $\begin{array}{c}\text { Tomato leaves, pond sediment, } \\
\text { igneous rocks, road dust }\end{array}$ \\
\hline $\begin{array}{l}\text { 2,6-Diacetylpyridine functionalized } \\
\text { Amberlite XAD-4 [ref. 29] }\end{array}$ & $\mathrm{Pb}$ (II): 0.43 & $\mathrm{~Pb}(\mathrm{II}): 238.1$ & Sea water, tap water \\
\hline 2-Aminothiophenyl S-acetic acid [ref. 2] & $\mathrm{Pb}(\mathrm{II}): 40.6$ & $\mathrm{~Pb}(\mathrm{II}): 0.03$ & Road dust \\
\hline This work & $\begin{array}{l}\mathrm{Pb}(\mathrm{II}): 30 \\
\mathrm{Ag}(\mathrm{I}): 38\end{array}$ & $\begin{array}{l}\mathrm{Pb}(\mathrm{II}): 0.35 \\
\mathrm{Ag}(\mathrm{I}): 1.5\end{array}$ & $\begin{array}{l}\text { Tomato leaves, pond sediment, igneous rocks, } \\
\text { road dust, geological sample, Silverex, } \\
\text { photographic washings }\end{array}$ \\
\hline
\end{tabular}


they are in good agreement with with the certified and reference values; no significant differences have been observed at a $95 \%$ confidence level according to a t-test. Results for road dust samples are also included in Table 3.

\section{Conclusions}

Polymeric resin containing derivatized amino acid are scarce and it is found that the developed method, based on polymer anchored derivatized L-methionine can be used for selective separation of $\mathrm{Pb}(\mathrm{II})$ and $\mathrm{Ag}(\mathrm{I})$ from different environmental and biological samples. The functionalities present in the solid polymeric matrix contain thio-ether, tertiary nitrogen (from amino acid part) and soft nitrogen from indole moiety which probably are responsible for binding to $\mathrm{Pb}$ (II) ion as per $\mathrm{HSAB}$ principle i.e., hard center always preferred to bind with hard center. Based on Table 5 , it can be concluded that the present method is one of the most promising $\mathrm{Pb}(\mathrm{II})$ and $\mathrm{Ag}(\mathrm{I}) \mathrm{SPE}$ extraction methods found in the literature. , $^{2,26-29}$

\section{Supplementary Information}

Supplementary Information data are available free of charge at http://jbcs.sbq.org.br as pdf file.

\section{Acknowledgements}

Financial assistance from DST (Govt. of W. B., India) is gratefully acknowledged. A. S. and S. M. are grateful to CSIR and UGC, New Delhi, India for providing fellowships.

\section{References}

1. Alegria, A.; Barbera, R.; Farre, R.; Lagarda, R.; Roig, M. J.; Romer, M. J.; Int. J. Environ. Anal. Chem. 1990, 38, 68.

2. Mondal, B. C.; Das, A. K.; React. Funct. Polym. 2002, 53, 45.

3. Dutta, S.; Das, A. K.; J. Appl. Polym. Sci. 2007, 10, 2281.

4. Gurnani, V.; Singh, A. K.; Venkataramani, B.; Anal. Chim. Acta 2003, 485, 221.
5. Goswami, A.; Singh, A. K.; Anal. Chim. Acta 2002, 454, 229.

6. Kumar, M.; Rathore, D. P. S.; Singh, A. K.; Talanta 2000, 51, 1187.

7. Cekic, S. D.; Filik, H.; Apak, R.; Anal. Chim. Acta 2004, 505, 15.

8. Matoso, E.; Kubota, L. T.; Cadore, S.; Talanta 2003, 60, 1105.

9. Saxena, R.; Singh, A. K.; Anal. Chim. Acta 1997,340, 285.

10. Kumar, M.; Rathore, D. P. S.; Singh, A. K.; J. Anal. Chem. 2001, 370, 377.

11. Chattopadhyay, P; Sinha, C; Pal, D. K.; Fresenius J. Anal. Chem.1997, 357, 368.

12. Higuchi, H.; Matsufuji, T.; Oshima, T.; Ohto, K.; Inoue, K.; Tsend-Ayush, T.; Gloe, K.; Chem. Lett. 2005, 34, 80.

13. Das, D.; Das, A. K.; Sinha, C.; Talanta 1999, 48, 1013.

14. Das, D.; Dai, Z.; Holmes, A.; Canary, J. W.; Chirality 2008, 20 , 585.

15. Holmes, A. E.; Das, D.; Canary, J. W.; J. Am. Chem. Soc. 2007, $129,1506$.

16. Zahn, S.; Das, D.; Canary, J. W.; Inorg. Chem. 2006, 45, 6056.

17. Rees, D. C.; Lewis, M.; Lipscomb, W. N.; J. Mol. Biol. 1983, $168,367$.

18. Borders, C. L.; Saunders, J. E.; Blech, D. M. Jr.; Fridovich, I.; Biochem. J. 1985, 15, 771.

19. Kim, E. E.; Wyckoff, H. W.; J. Mol. Biol. 1991, 218, 449.

20. Dreyer, M. K.; Schulz, G. E.; J. Mol. Biol. 1993, 231, 549.

21. Nakon, R.; Rechani, P. R.; Angelici, R. J.; Inorg. Chem. 1973, 12, 2431.

22. Stork, G.; Leong, A. Y. W.; Touzin, A. M.; J. Org. Chem. 1976, $21,3491$.

23. Vogel, A. I.; A Textbook of Quantitative Inorganic Analysis, $3^{\text {rd }}$ ed., Longmans: London, 1961.

24. Frost A. A.; Pearson, R. G.; Kinetics and Mechanism, Wiley: New York, 1953.

25. Turse, R.; Rieman III, W. M.; J. Phys. Chem. 1961, 65, 1821.

26. Mondal, B. C.; Das, D.; Das, A. K.; Anal. Chim. Acta 2001, 450, 223.

27. Das, D.; Das, A. K.; Sinha, C.; Anal. Lett. 1999, 32, 567.

28. Dutta, S.; Das, A. K.; J. Sci. Indian Res. 2007, 66, 1025.

29. Kara, D.; Fisher, A.; Hill, S. J.; Analyst 2005, 130, 1518.

Submitted: May 5, 2010

Published online: September 28, 2010 
A New Chelating Resin Containing Indole-Methionine Composite: Synthesis, Characterization and Determination of Lead and Silver after Preconcentration in Biological and Environmental Samples

\section{Animesh Sahana, ${ }^{a}$ Srikanta Mandal, ${ }^{a}$ Arnab Banerjee, ${ }^{a}$ Subarna Guha, ${ }^{a}$ Subhra Kanti Mukhopadhyay*,b and Debasis Das ${ }^{*, a}$}

${ }^{a}$ Department of Chemistry and ${ }^{b}$ Department of Microbiology, The University of Burdwan, Burdwan 713104, India

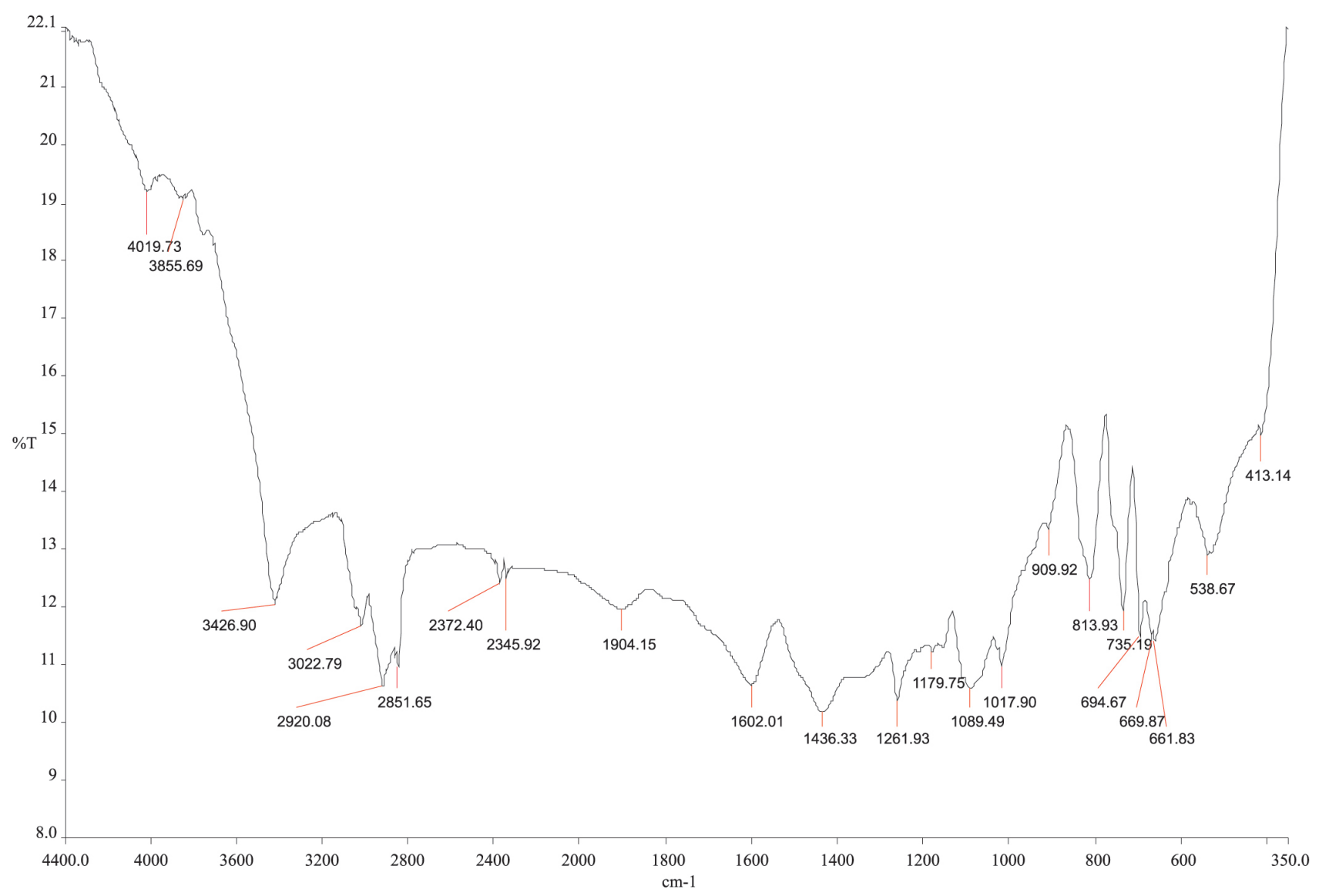

Figure S1. FT-IR spectra of the IM resin. 


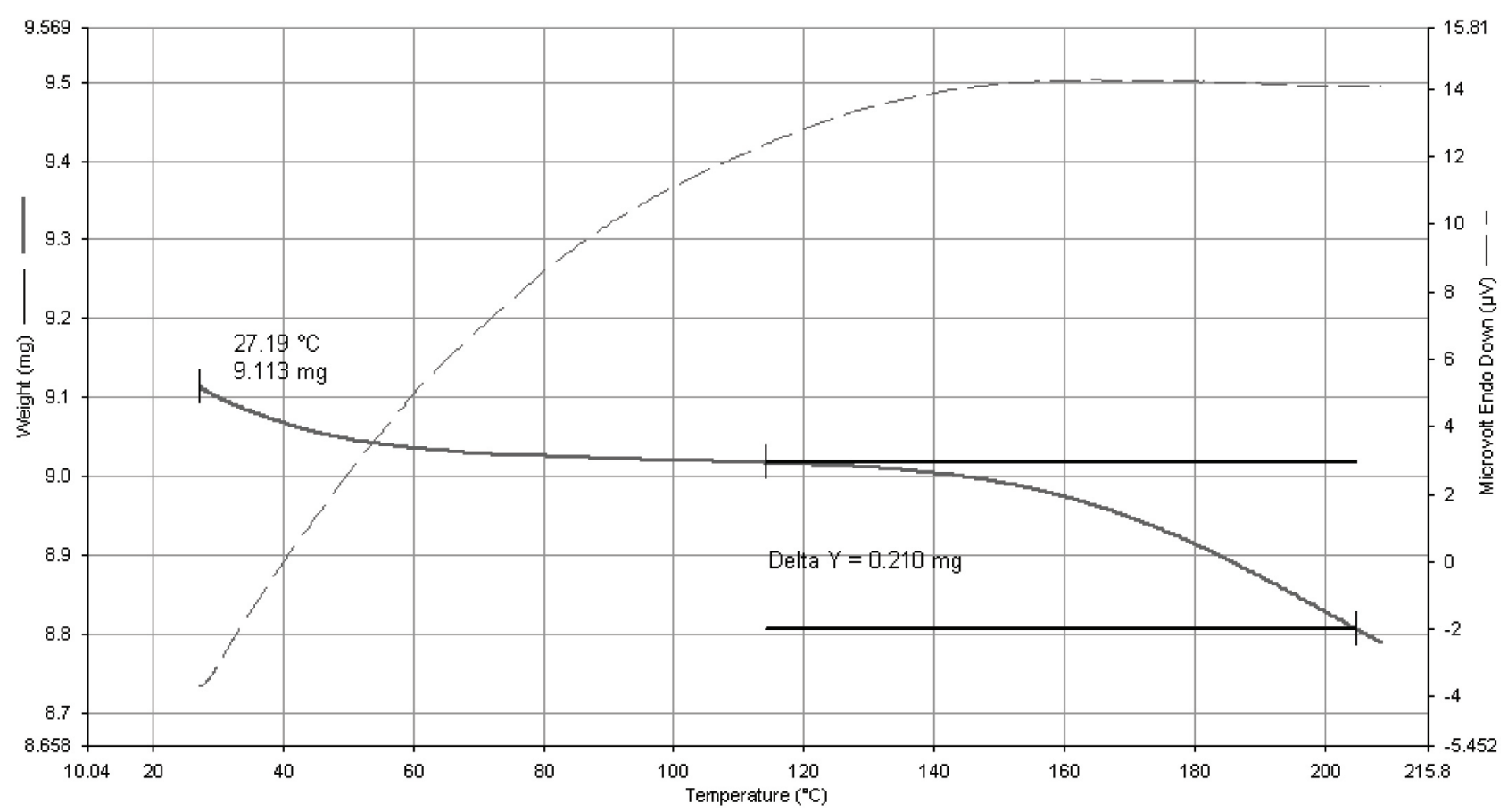

Figure S2. TGA/ DTG of the IM resin.

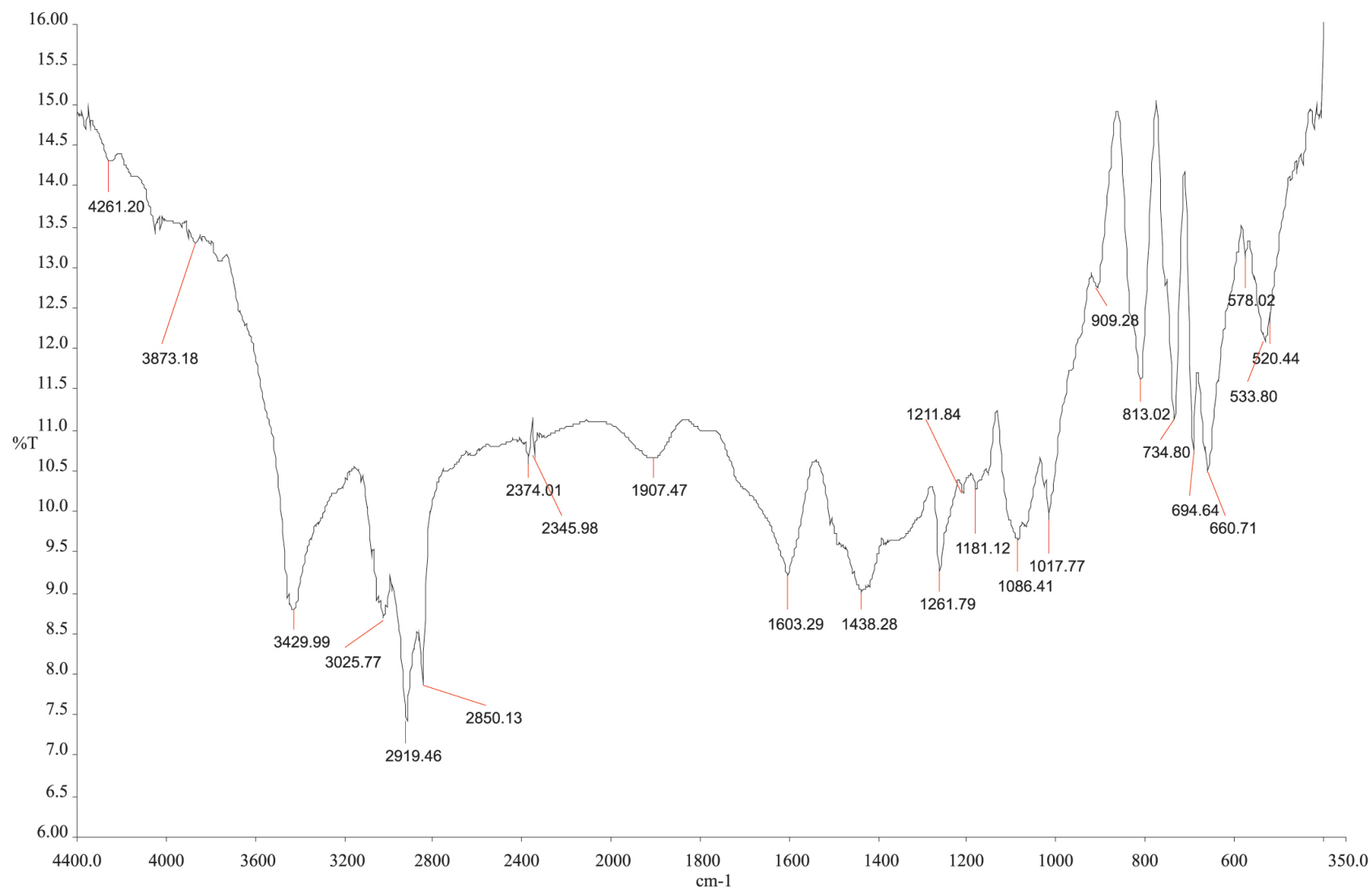

Figure S3. FT-IR spectra of the $\mathrm{Pb}^{2+}$ loaded IM resin. 


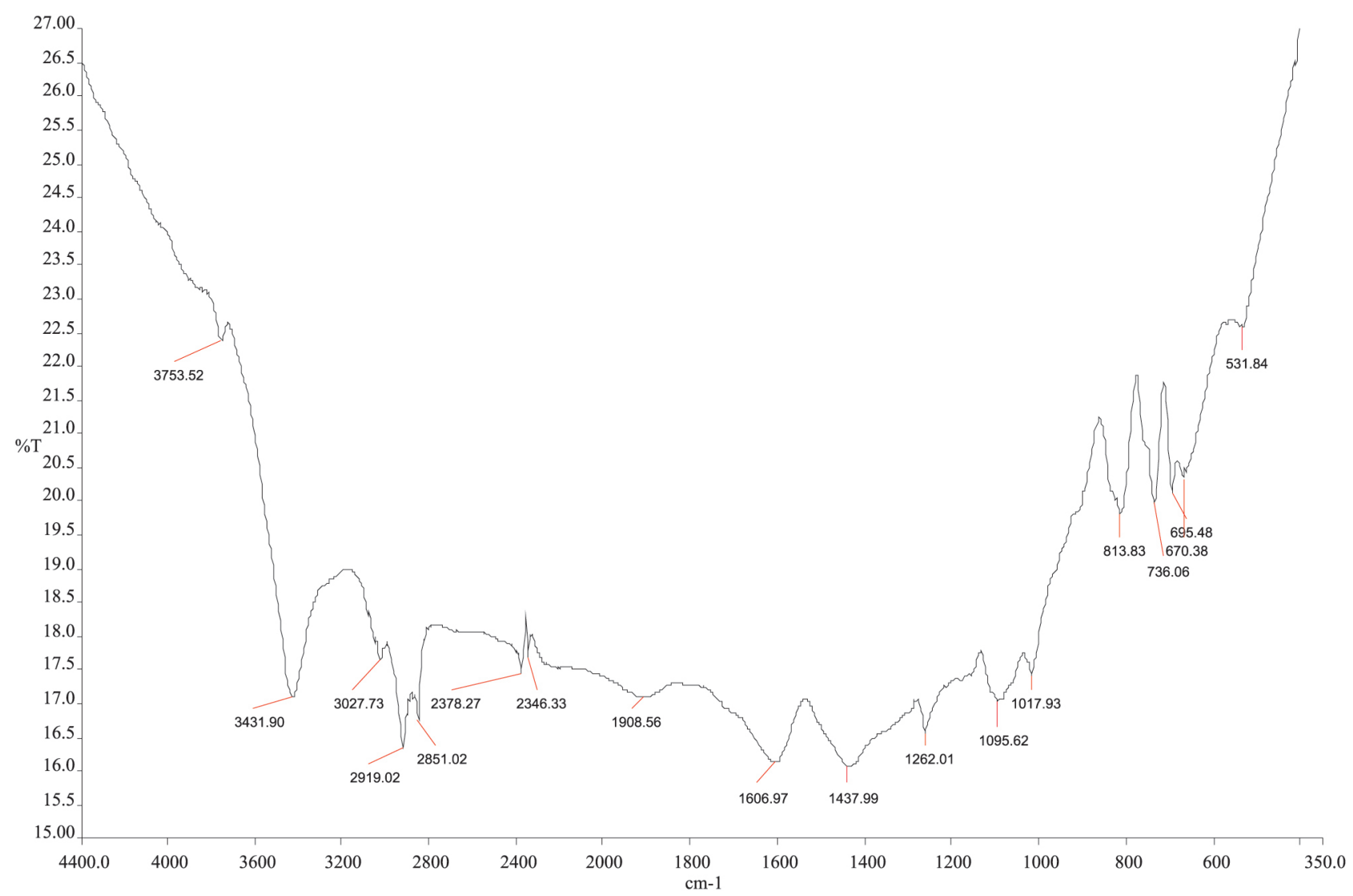

Figure S4. FT-IR spectra of the $\mathrm{Ag}^{+}$loaded IM resin. 